\title{
PERCEIVED JUSTICE AS A CRUCIAL FACTOR OF PERFORMANCE MANAGEMENT SYSTEMS
}

Academic journals lack recent research on the state of Performance Management (PM) practices and their assessment in a comprehensive manner. By examining the current trends in line with the research, this article narrows the gap between practice and research and delivers practical recommendations. Based on the four criteria of effectiveness the article describes the comprehensive framework for evaluating the effectiveness of PM systems and highlights the importance of justice perception as one of the effectiveness criteria. The article displays the findings of secondary research about the new PM systems introduced recently by companies, and analyzes the main driving forces of the changes. The general characteristics of the traditional and emerging trends are described and defined as "competitive" and "cooperative" approaches in comprehensive framework. The conclusion of the article is twofold. Firstly, one cannot speak about major changes of PM, but there are signals of a shift from the "competitive" to the "cooperative" approach, which can be explained by situational changes, and the organizations should match their PM with their own situations. Secondly, fairness perception as one of the employees' reactions to PM is a crucial criteria for effectiveness and it is related to the success or failure of the system.

Keywords: performance management, performance appraisal, perceived justice, perceived fairness

$\mathrm{T}$ he main question of Human Resource Management (HRM), as a support function to leadership, is how to make an employee as effective as possible in achieving organizational goals. It is assumed that employees' individual performances lead to intended organizational performance if individuals' goals are in line with organizational goals. Performance Appraisal (PA) as an integral part of Performance Management (PM) system has been considered as one of the most important HR process, because it provides the best chance to establish a link between individual performance improvement and firm performance improvement (DeNisi - Murphy, 2017).

It took a long journey for researchers to start to focus on performance improvement more as a goal of appraisals (DeNisi - Pritchard, 2006). In the past, research on PM has not had the impact it could have on the practice, mainly because it has focused on the quantitative criterion, that refers to the validity and reliability of the measurement tools, while researchers paid less attention to the qualitative criterion, that refers to the individual justice perceptions of these tools and practices, that affect employees' attitudes and behavior in the workplace (Farndale et al., 2011).

Despite the fact that PM have been subject to many criticisms in the past, the theory resonates to the practical problems of the current period. The historical and economic context has played a huge role in the evolution of PM practices and research over the decades (DeNisi - Pritchard, 2006). Researchers have been dealing with those issues, which drew attention of the practitioners, time to time. Furthermore, the research lines dealing with psychometric soundness of rating formats highlighted those unsolved issues, which made researchers move attention finally to measures that reflected ratee perceptions of fairness and accuracy (DeNisi - Murphy, 2017).

As justice perception of performance appraisal has been identified as an important criterion in judging effec- tiveness and usefulness of PM for organizations, the contextual factors outside the appraisal process became also important because they may influence justice perceptions of performance appraisal (Erdogan, 2002).

PM researchers made a significant progress when they came to better appreciate the critical influence of the context in which performance appraisal occurs on the process and outcomes of appraisal (Erdogan, 2002; Murphy - DeNisi, 2008). PM research can not make significant contribution in understanding how or why one appraisal succeed and the other not without considering why appraisals are conducted and how the contextual factors shape the appraisal process and outcomes of the appraisal (Biron et al., 2011; DeNisi - Murphy, 2017).

However many research published in this topic are still mainly decontextualized, examining different facets and features of the process in isolation (DeNisi - Murphy, 2017). Other studies may stress out the importance of specific contextual variables such as national or organizational culture, leader-member exchange quality, perceived organizational support (Erdogan, 2002; DeNisi - Murphy, 2017) or the features of an effective implementation (Aguinis et al., 2011; Longenecker - Fink, 2017).

Nonetheless studies are also published such as motivational framework (DeNisi - Pritchard, 2006), integrated framework (Iqbal, 2015) and the conceptual framework of using competing values approach (Ikramullah et al., 2016), which met the demand to integrate the results of previous PM research.

According to contingency theory the design of an organization and its subsystems must have a proper fit with the environment and its subsystems should be also consistent with one another (Lawrence - Lorsch, 1967). Based on this premise, HR aims to develop adequate PM systems in line with the organization's business model. While the PM system should also be consistent with other HR subsy- 
stems, such as compensation, succession planning, talent management, career development, learning and development and with other systems in the organization such as strategy, business planning and controlling. HRM should ensure that processes are running along the same principles and standards across the organization, while providing efficient support to the top and middle management.

The effectiveness of PM systems should be assessed and examined in a more comprehensive manner, in which PM systems are built in a way that they are in line with their situation and users' justice perception. Based on this as an integrated view, the practical implication of the conceptual framework of Ikramullah et al. (2016) can have a great added value to narrow the gap between practice and research.

Drawing on the direct aim of enhancing the effectiveness of PM systems in improving employees' performance, my research questions are formulated as follows: how can PM be effectively designed and implemented in line with its external and internal situations and organizational structure by applying the conceptual framework of using competing values approach? What are the differences and common characteristics of the PM systems implemented recently and what are the main driving forces related to these characteristics?

Research on PM dates back to the early 1920s and based on that one can assume practitioners could find out how to design and implement PM systems in line with their strategic and business goals and situations effectively. However there are very few specific recommendations about designing and implementing PM whose goal is performance improvement. Furthermore "a perusal of the literature reveals that recent research on the state of PM practices is solely lacking in academic journals" (Gorman et al., 2017, p. 193.). My aim is to narrow the gap between practice and research by examining the current trends in line with the research and give practical recommendations how to change or improve their PM practices in order to enhance the effectiveness of PM as a whole.

In recent years many articles were published in business journals with provocative headlines about the end of traditional performance management. Big multinational companies decided to get rid of their traditional PM systems and start to rethink the way they conducted their procedures (Buckingham - Goodall, 2015; Cappelli - Tavis, 2016; People \& Strategy, 2016; Kinley, 2016). These give the impression that we are witnessing a major change of PM.

This paper is structured as follows. First, in Section 2 I define PM system, then in Section 3 I discuss the PM literature with the different lines of PM research. Based on the four criteria of effectiveness I introduce the Ikramullah's comprehensive framework for effectiveness of performance appraisal systems (Ikramullah et al., 2016). Then I highlight the importance of justice perception as one of the effectiveness criteria and describe Greenberg's (1993) taxonomy of justice perceptions applied to performance appraisal (Thurston, 2001 in Walsh, 2003). Secondly, I conduct a secondary research, which involves a review of journals on one hand, and data available online about the new PM systems introduced between 2012 and 2017 by multinational companies on the other. As far as the latter source of data is concerned instead of studying the entire population, I selected a sample of companies which are important actors in the market. By generalizing the results in order to eliminate my personal bias in the selection, I focus on the general patterns that appeared in different companies. In Section 4 I provide a brief overview about the evidence of the market. In Section 5 I analyze the main driving forces of the changes by differentiating internal and external situations and organizational structures. I describe the general characteristics of traditional and emerging trends and rename them as "competitive" and the "cooperative" approaches of PM systems and put the approaches in comprehensive framework for effectiveness. Finally, in Section 6 I give recommendations on how PM system can be improved and in Section 7 I also discuss what the possible further research directions can be.

As a conclusion, first, I found that the organizations should fit their PM systems with their own situations in order to set up an effective system. Based on the review we cannot speak about major change of performance management, but there are signals of a shift from the "competitive" to the "cooperative" approach, which can be explained by situational changes. Secondly, fairness perception as one of the employees' reactions to PM system is a crucial criteria for the effectiveness of PM systems and it is related to the success or failure of the system. Recent changes highlight the unsolved issues of psychometric soundness of rating formats, since it is not the validity and reliability of the measurement tools but the individual justice perceptions of these tools and the related practices that affect employees' attitudes and behavior.

\section{Performance Management System and Performance Appraisal System}

Nowadays researchers and practitioners tend to assume that employees' individual performances lead to intended organizational performance if individuals' goals are in line with organizational goals (DeNisi - Murphy, 2017). The relevance of PM systems and practices is that they aim to establish a link between individual performance improvement and firm performance improvement.

Like every other organizational system, PM is to provide efficient support to the management to fulfill its coordination task. In order to coordinate, it is management's responsibility to set strategic goals and objectives, to cascade organizational goals into individual goals, to control past and present achievements and give feedbacks accordingly in order to foster future performance in line with organizational goals. Within the leadership function managers convey goals to the employees, motivate them by compensation, future career opportunities and development. $\mathrm{PM}$ is the result of the organizing function of management.

PM is an integral part of the annual business planning cycle. PM system enables managers to cascade the strategic targets into team and individual performance objectives and development plans; to reinforce sense of accountability and performance-oriented culture in the organization; to enhance employees' motivation and commitment, and to evaluate the capabilities of people for future business challenges. From 
the individual's point of view PM system is important to clarify job responsibilities, expectations and priorities; to provide feedback and coaching; and to enable systematic dialogue about longer-term career aspirations and personal development (Bakacsi, 1999). The main goal of PM-related HRM practices is to increase organizational performance through individual and group performance by improving performance-related behavior such as motivation, job satisfaction, organizational commitment and trust, cooperation, compliance and acceptance of decisions and by decreasing "bad" behavior outcomes such as silence, absenteeism, fluctuation and conflict (Conlon - Meyer - Nowakowski, 2005).

Performance Appraisal (PA) as part of PM system refers to the whole procedure, including the establishment of performance standards, appraisal-related behaviors, the determination of performance ratings, and the communication of the rating to the ratee (Erdogan, 2002). The goal of PA is to provide information that will best enable managers to improve individual performance (DeNisi - Pritchard, 2006). Furthermore an effective PA is an "engine" of the HRM, providing essential information to all other HR systems in order to support decisions of compensation, succession planning, talent management, career development, learning and development planning (Bakacsi, 1999; Biron et al., 2011). Since PA is an integral part of PM, hereinafter whether I refer PA as PM, or I make a clear distinction between the two concepts, only when I find it necessary.

\section{Literature review}

Even though the interest in evaluation of performance at work can be tracked back in ancient China and there were also efforts at establishing merit ratings as far back as the 19th century (Murphy - Cleveland, 1995 in DeNisi - Murphy, 2017), psychological research on performance rating began only in the 1920s, with Thorndike's article (Thorndike, 1920 in DeNisi - Murphy, 2017) in which he identified what eventually became known as "halo error."

There were two important trends, which defined performance appraisal practices in the Anglo Saxon and Western European cultures. Firstly, the evaluation methods have been shifted gradually towards behavioral and outcomebased approaches from personality traits and informal (essay-type) evaluation. Secondly, the application of the performance appraisal system has become more and more numerous and the number of goals that formal evaluation systems have to achieve was also growing such as administrative goals for promotion, dismissal and salary raise, later training and development in individual and organizational level, then finally organizational planning, legal documentation and guidance for the evaluation and development of the personnel system. Owing to this central role, the multifaceted goals, and the frequently changing performance criteria in changing environments, performance assessments are surrounded by many conflicts (Takács, 2001).

Despite the fact that PM has been subject to many criticisms in the past, it seems that historical and economic context has played a role in the evolution of PM practices and research over the decades. The organizational and managerial needs served as driving forces in developing new research lines in the field (DeNisi - Pritchard, 2006).

In their literature review in Journal of Applied Psychology DeNisi and Murphy (2017) defined nine substantive subareas that dominate performance management and appraisal research: (1) rating scales, (2) evaluating the quality of rating data, (3) training (4) reactions to appraisal, (5) purpose for appraisal, (6) rating sources, (7) demographic effects, (8) cognitive processes (9) PM research. The authors emphasize that the rating scales and evaluating the quality of rating data research - that is assessing the reliability, validity, or accuracy of performance ratings -, underlined the problems with more traditional criteria for evaluating the effectiveness of appraisal systems. These research lines made a significant impact by moving the attention from traditional error measures to accuracy measures and eventually to measures that reflected ratee perceptions of fairness and accuracy. After 50-year dominance of rating research the reactions to appraisal research began in the 1970 s by focusing on ratee satisfaction and perceptions of fairness. This direction of research has been especially important because "it helped move the field to consider other types of outcome measures that could be used to evaluate appraisals systems" (DeNisi Murphy, 2017, p. 425.). The concept of justice perceptions have become a significant part of later models of PM such as the work of DeNisi and Smith (2014) and many researchers suggest that justice perception remain as an important research line in the future (DeNisi - Murphy, 2017).

As every research line aims to improve the effectiveness of PM systems, studies suggest that there are four criteria of effectiveness, in which each research line can be classified: utilization, qualitative, quantitative and outcome criterion. The utilization criterion refers to purpose achievement, which addresses the question why appraisals are conducted. The qualitative criterion refers to the justice perceptions of a performance appraisal system related to a set of rules and practices. The quantitative criterion refers to psychometric soundness of rating formats, focusing on enhancing appraisal accuracy and minimiz-ing rating errors and biases. The outcome criterion refers to appraisee reactions, in terms of both person- and organization-referenced outcomes reflects on appraisees' attitudinal evaluations of and responses to the system.

Utilization, qualitative and quantitative criteria are considered incomplete unless these are linked to the outcome criterion. Regarding the qualitative criterion without assessing "fair process effect" (Folger et al., 1979 in Ikramullah et al., 2016) justice cannot be done. The literature highlighted that fairness perceptions are one of the employees' reactions to PM system and are related to the success or failure of the system (Smither, 1988; Taylor et al., 1995; Murphy - Cleveland, 1991; Erdogan et al., 2001 in Ikramullah et al., 2016). Individuals' attitudes and behaviors can be determined by their perceptions of reality, not reality per se (Lewin, 1936 in Ikramullah et al., 2016). 


\section{Comprehensive framework for effectiveness of performance appraisal system}

The literature has pointed out a wide array of deficiencies related to many existing PM systems such as failure to pursue and achieve PM purposes; lack of reliable, valid and objective performance measures; appraisers' dependency on human information processing and rating judgments; inability to meet expectations of the key stakeholders; weak interpersonal relationships between appraisers and appraisees, which in turn, increase interpersonal conflicts and dwindle trust and communication between them (Ikramullah et al., 2016).

The effectiveness of PM system should be assessed and judged not on the basis of a single standard, but multiple criteria that include values and preferences of all major stakeholders of the system, i.e., appraiser, appraisees and the organization (HR department and the top management). To provide a guideline for professionals to consider the effectiveness of performance appraisal system Ikramullah et al. (2016) propose a comprehensive framework for effectiveness of performance appraisal system, which is based on the competing values framework of Quinn and Rohrbaugh (1983) (Quinn - Rohrbaugh, 1983 in Ikramullah et al., 2016).

The competing values framework represents the competition between stability and change, and between internal organization and the external environment. Based on these two competing dimensions the comprehensive framework for effectiveness of performance appraisal sys-tem includes four quadrants: internal process model, rational goal model, human relations model and open system model (Denison - Spreitzer, 1991 in Ikramullah et al., 2016).

Internal process model (control and internal focus) highlights control, stability, information management, communication and continuity. Its main assumption is related to the process (e.g. clarity of responsibilities, measurement, documentation and record keeping) governed by clear rules and strictly followed by its users. It includes assigning qualified appraisers; giving regular feedbacks; appraising performance and recording in on a psychometrically sound rating format; giving access to information and weight to voice of appraisees.

Rational goal model (control and external focus) includes planning, goal setting and efficiency. This model constitute a link between clear and certain organizational goals, and performance improvement. To enhance effectiveness, companies set goals, develop plans and then take actions to accomplish these goals.

Human relations model (flexibility and internal focus) highlights employee development, and morale and group cohesion. The appraisers are encouraged to seek appraisees' participation while making appraisal-related decisions. Appraisers need to coach their subordinates and emphasize employee development through training and development programs not only for improving on their current performance but also to meet future workforce needs.

Open system model (flexibility and external focus) underlines flexibility, readiness, out-spacing competition, growth and acquiring resources. It focus on creative problem solving, innovation, adaptability and manage- ment of change by defining flexible performance targets and role-definition purposes. Due to the development of technology, globalization and workforce diversity there are many variations occur in work setting and organizational structures and employees have to develop new skills and perform different tasks.

Each key stakeholder has different values and preferences, however the PM system should be effective in all four areas. These models can be good representations of the four criteria of effectiveness of PM systems (Ikramullah et al., 2016) (Figure 1).

\section{Figure 1 Competing value framework for an effective} performance appraisal system

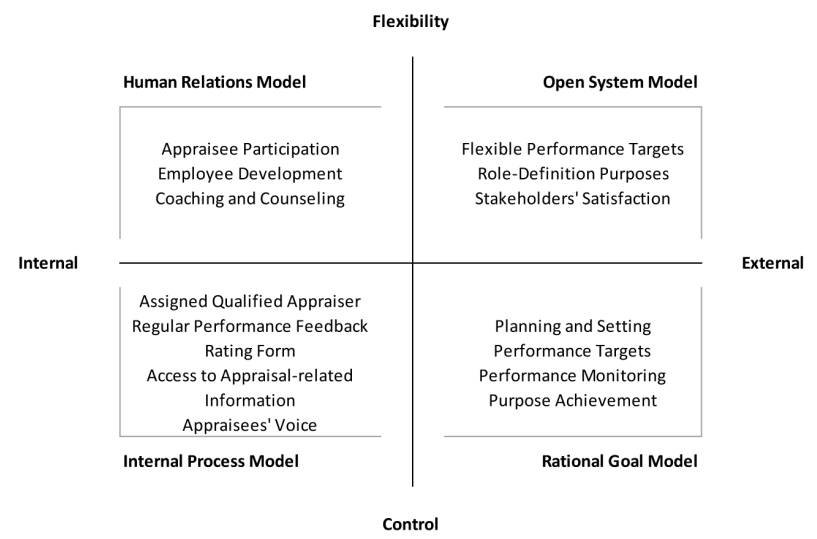

Source: Ikramullah et al. (2016): Effectiveness of performance appraisal; Personnel Review, 45, 2, p. 341.

\section{Perceived justice in performance management}

Based on the review, perceived justice research has significant roots in the field and fairness perception as one of the employees' reactions to PM system has been identified as an important criterion in judging the effectiveness and usefulness of performance appraisal. Since not the validity and reliability of the measurement tools but the individual justice perceptions of these tools and practices affect employees' attitudes and behavior in the workplace.

Little attention has been paid to the employee perspective, although employees eventually are the recipients of and their performances are subjects to the PM systems (Farndale et al., 2011).

The impact of HR practices on employees' commitment and performance depends on employees' perception and evaluation of these practices. The perception and attitudes may mediate and moderate the relationship between HRM practices and these employee performance-related behaviors.

Different employees are often assumed to perceive the employment practices offered by the organization similarly, however variation may exist in employees' perceptions of HRM practices or benefits offered by the organization even when in objective terms what is offered to different employees is similar. (Hartog et al., 2004; Boon et al., 2011)

The contemporary theories about justice mainly concentrate on how individuals perceive justice, how they consider and investigate the subjective and phenomenological appraise, a given stimulus or situation. Within this approach something 
is considered to be "fair" not because it should be (normative), but because some people perceive it to be so (descriptive) (Cropanzano - Bowen - Gilliland, 2007; Greenberg - Bies, 1992). The research of perceived fairness of performance appraisal systems in the 1970's and 80's has identified the fairness of the evaluation with the fairness of distribution. From the 80's however the researchers' attention was more and more shifted towards the fairness of the procedures, then later the fairness of interpersonal treatment received during the execution of the procedure (Bies - Moag, 1986).

Conlon, Meyer and Nowakowski (2005) distinguished four dimensions of justice: distributive justice, procedural justice, informational justice and interpersonal justice.

Distributive justice refers to the perceived fairness of outcome distribution. The distributional justice refers to the outcome of the distribution based on the norm, which the participants have agreed upon previously. Distributive injustice can arise in such situations when the actual allocation is not in line with these normative expectations. According to the justice literature there are three types of distributional norms: equity, equality and need. The equity theory (Adams, 1965 in Erdogan, 2002) argues that each person compares their input-output ratios with those of others in order to determine the level of fairness. When employees perceive inequity, they try to rebalance it by modifying their efforts or outcomes or by changing their perceptions of inputs or outputs. In PM, employees compare their efforts with the rating they get and the fairness of the rating creates distributive justice perceptions (Erdogan, 2002). The equality principle traditionally means that equal amounts go to each recipients regardless of any other factors such as their inputs (Cook - Hegtvedt, 1983). Although equality meant to be less widely accepted by individuals, this principle is most commonly used in everyday life, since heuristics can be applied more easily than rules in complex decision-making situations (Gerákné, 2008a). Principle of need argues that those individuals in grea-test needs should be provided more resources to meet those needs. This distribution principle is limited in organizations because the needs are not related to performance, but they indicate some kind of special treatment, which is often difficult to justify (Mező - Kovács, 1999 in Gerákné, 2008a).

According to intercultural studies, individualist cultures tend to apply equity principles, while collectivist cultures are based on the principle of equality theory mostly (Ramamorthy - Flood, 2002 in Gerákné, 2008a). According to Deutsch (1982), the application of the principles is rather influenced by the nature of the relationship between the parties: if the relationship is for profit, equity plays a role, if the relationship is for joy, equality is more dominant and if the relationship is for development and prosperity, then the principle of need comes to the fore (Berkics, 2008). The choice of principle at the organizational level is influenced by the nature of work, and the organizational and national culture. At the same time, the preferred distribution principle may be influenced by egocentric bias, profit maximization, and fundamental attribution error at the individual level.
Procedural justice refers to the structural aspects of the decision-making process by which performance is evaluated. The importance of procedural justice is based on the control theory of Thibaut and Walker (1975) and the group-value model of Lind and Tyler (1988). According to control theory individuals have a desire to control what happens to them, while the group-value model argues that individuals have a desire to be valuable members of their groups and a fair procedure indicates that they are valued (Erdogan, 2002).

Bies and Moag (1986) defined interactional justice as the fairness of interpersonal treatment received during the execution of a procedure and underlines the importance of truthfulness, respect, and justification as fairness criteria of interpersonal communications. According to the justice literature the interactional justice consists of two components: informational justice and interpersonal justice. Informational justice refers to the quantity and quality of the information provided during the process. Informational justice contains the overlapping areas of interactional and procedural justice types. As Erdogan (2002) also claims that procedural justice can be conceptualized as two related, but still distinct construct reflecting system procedural justice and rater procedural justice (Walsh, 2003). Interpersonal justice refers to the social aspects of distributive justice, it describes how respectfully we deal with each other (Conlon - Meyer - Nowakowski, 2005). Interpersonal justice can include the form of any social rewards provided by the supervisor or injustice such as an insult which is defined as a social interaction and an outcome (Mikula - Petrik - Tanzer, 1990 in Walsh, 2003). A manager's respectful behavior can be considered as a socio-emotional award.

The perceived justice is influenced by all the elements of the four justice dimensions, and they often interact with each other. Since the employees usually have limited information about the outcome of the distribution of others, they can not make a proper social comparison about their input/output rate. The significance of procedural justice is based on the assumption that employees have easier access to procedural elements than output information, so each individual can make justice judgments based on their impressions on the process and they try to integrate their knowledge about the output into that.

Greenberg (1986) was the first one, who applied the theory of organizational justice in performance management, and later Greenberg (1993) established a four-categories of justice perceptions model: (a) systemic (structural-procedural), (b) informational (social-procedural), c) configural (structural - distributive), (d) interpersonal (social-distributive) (Cropanzano - Bowen - Gilliland, 2007).

This model consists of two dimensions: distributive/ procedural and structural/social dimension. The distributive justice perceptions concern outcome allocations, while procedural justice perceptions concern how allocation decisions made. The structural components define the context of decision making for processes and outcomes, while the social components imply the quality of interactions during the communication of processes and outcomes. In Table 1 
the concerns regarding the justice implication of PM system are summarized based on Walsh (2003).

Table 1 Taxonomy of Justice Perceptions Applied to Performance Appraisal

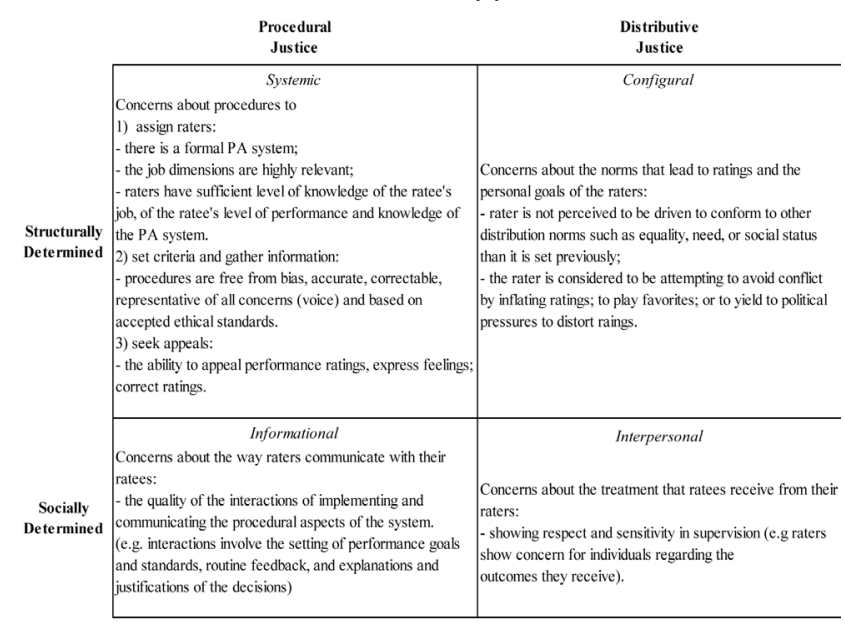

Source: edited based on Greenberg's (1993) Taxonomy of Justice Perceptions Applied to Performance Appraisal (Thurston, 2001 in Walsh, 2003)

Greenberg's (1993) conceptualization of the four types of justice offers the opportunity to more comprehensively study and organize employees' perceptions of fairness concerning performance appraisal systems. Later Colquitt (2001) has also developed a questionnaire to assess the perceived organizational justice among employees. Greenberg's description of the perceptions of fairness and the questionnaire of Colquitt (2001) may provide practitioners with valuable information to better manage the complex system of PM (Colquitt, 2001).

There are many research dealing with perceived fairness in connection with organizational commitment, helpful citizenship behaviors, job satisfaction, attitude predicting individual's behavior, engagement, trust and turnover intentions, however there is not still a common understanding how these factors have an effect on one another. For example the connection between trust and justice is two-sided. Trust influences what we consider as fair, but justice also affects whether we can trust the other party or not (Sass, 2011). Farndale et al. $(2011,2013)$ found that perceived justice leads to increased levels of employee commitment, moderated by employee levels of trust in the employer (Farndale et al., 2011; Farndale - Kelliher, 2013). Organizational units with high trust in senior management have both higher levels of commitment, and indicate a stronger link between employee perceptions of fair treatment by their line managers during performance appraisal, and organizational commitment (Farndale - Kelliher, 2013). Findings also show the link between employee experiences of high commitment performance management practices and their level of commitment. This link is strongly mediated by related perceptions of organizational justice. Furthermore, the level of employee trust in the organization is also a significant moderator (Farndale et al., 2011). Other studies show employees' perceived fairness has an effect on attitude, which can predict individual's behavior. „Good” organizational outcomes include performance, compliance, acceptance of decisions, and cooperation, while "Bad" organizational outcomes comprise of silence, absenteeism, and fluctuation (Conlon - Meyer - Nowakowski, 2005). Several studies deal with the relationship between perceived organizational justice and work stress (Cropanzano et al., 2005; Szilas, 2014). Based on the results of another study, organizational justice can foster trust and commitment, improve job performance, can induce more helpful citizenship behaviors, improved job satisfaction, and diminished conflict (Cropanzano et al., 2007). Justice perceptions in performance appraisals influence organization-related (i.e. commitment, turnover intentions), leader-related (i.e. prosocial behaviors targeting the supervisor, satisfaction with the leader) and performance-related outcomes (i.e. task performance, motivation to improve), through improved exchanges with the organization and the leader, and through increased accountability pressure (Erdogan, 2002).

\section{Evidence from the market}

Bokor (2011) conducted a survey to examine the HR function in Hungarian companies. The results showed that although managers considered PM important, they were strongly dissatisfied with it (Bokor, 2011). These results are in line with the international trends. In an American survey only $20 \%$ of managers found their PM effective, while in an international survey this rate was 5\% (Barrier, 1998). According to another study $91 \%$ of HR professionals indicated that their organization has a formal PM (World at Work, 2010). However less than half argued that the system has helped the firm to achieve its strategic goals. Only $27 \%$ indicated their employees trust the system and 47\% stated that PM viewed as an "HR process" instead of a business-critical process. Even though more than half invest in manager and employer training to make PM more effective, only $28 \%$ of the companies felt their managers focus on having effective performance dialogues, rather than just completing forms.

Recently many articles were published with provocative headlines about the end of traditional PM. Big multinational companies announced of getting rid of their traditional PM systems and start to reinvent the way how they conducted their procedures (Buckingham - Goodall, 2015; Deloitte, 2015; Rock - Jones, 2015; Cappelli - Tavis, 2016; Ewenstein, 2016; People \& Strategy, 2015; Kinley, 2016; Gorman, 2017). It seems that we are witnessing a revolution of performance management. Deloitte reported that only $12 \%$ of the U.S. companies were not planning to rethink their PM systems in 2015. PwC also reported that two-thirds of large companies in the UK are in the process of changing their systems (CappelliTavis, 2016). In a subsequent U.S. study respondents considered PM the most important HR system and agreed that the use and the significance of PM will further increase in the future (Hays - Kearney, 2001; Goodman - French - Battaglio, 2015).

\section{Pioneer Employers}

Pioneer companies, which redesigned their PM systems in the last 6 years to boost organizational performance can be divided into three groups: technology compani- 
es, professional service firms, and other early adopters in other industries.

Technology companies (Adobe, Microsoft, IBM, Dell, Juniper Systems, Medtronic)

In 2009 Juniper Systems found the classic PM system to be a barrier to its goal of disruptive innovation and it launched a redesigned PM process. Since then however some PM components have changed and evolved based on the feedback of their colleagues and managers. In 2011 Adobe also ended its annual performance reviews and has gone totally numberless but still gives merit increases based on informal assessments. In the same year Medtronic, a developer and manufacturer of medical device technology and therapies, rethought its PM system in order to move away from competitive assessment toward providing real-time performance feedback, coaching and development sessions for its employees. In 2015 IBM, Microsoft and Dell also joined as early followers (Cappelli Tavis, 2016; Zillman, 2016; Ewenstein, 2016).

Professional service firms (Deloitte, KPMG, PwC, Accenture, Kelly Services)

Kelly Services, which provides workforce solutions and offers a comprehensive array of outsourcing and consulting services, was the first big professional services firm to drop its old PM system in 2011 (Cappelli - Tavis, 2016). After pilot testing in 2013 PwC also discontinued annual review for all its employees, and then Deloitte, KPMG, and Accenture followed suit in 2015 (Buckingham - Goodall, 2015). Given not just the sheer size of these compa-nies, but the fact that they offer management consultancy to many organizations in a broad range of industry sectors, acting as pioneers the choices of these companies are having a huge impact on others. Furthermore, they can also offer HR solutions to their clients later on based on the experiences of their transformation of their PM systems.

Early adopters in other industries (GE, Sears, GAP, Oppenheimer Funds, Eli Lilly, Mitre, Lear)

In order to foster performance at team level and track collaboration Sears and GAP, which is on the top 100 list of largest U.S. retail chains, became also early innovators in their sector (Deloitte, 2017). Customer service now requires frontline and back-office employees to work together to keep shelves stocked and manage customer flow (Cappelli - Tavis, 2016). Even General Electric, which is a longtime role model for traditional PM, backed away from forced ranking because it fostered internal competition and undermined collaboration and reinvented its PM in 2015 (Ewenstein, 2016). It was also reported that Oppenheimer Funds, Lear, Eli Lilly and Mitre have changed their systems (Cappelli - Tavis, 2016; People \& Strategy, 2016).

\section{Discussion}

In the followings I will summarize the main driving forces and the general patterns of the changes in PM systems introduced between 2012 and 2017 by the sampled multinational companies. Then I will differentiate "competitive" and the "cooperative" approaches of PM systems.

\section{What are the main driving forces?}

In this study I apply a strategic contingency perspective that assumes that the alignment between HRM practices and the firm's strategy is associated with the firm's profitability; and the applied HRM practices as a leadership support function meet specific contingency factors and are appropriately configured.

I discuss those variables such as the internal and external environment and the organizational structure that have impact on organizational performance and organizational behaviour.

\section{External situation}

There is a rapidly changing, uncertain market environment especially in sales and in labor market. The business need is to prototype more quickly and responding in real time to customer feedback and changes in requirements (Ewenstein, 2016).

Competitive intensity continues to increase in the global market economy. Multinational companies globalize and access new talent at lower costs. Even market leaders can lose their position more easily (Deloitte, 2011). Labor market is booming and employee retention has become critical again (Cappelli - Tavis, 2016). The former, more transactional view of performance turned out to be difficult to support in an era of low inflation and tiny merit-pay budgets. If the inflation rates shoot up or the bonuses are not treated as regular income and singled out for favorable tax treatment, merit based pay comes into focus in appraisal process. In these cases, annual salary increases and bonus payment really can matter and the pressure is on to award more objectively. As a result, accountability can become a higher priority of development for organizations (Cappelli - Tavis, 2016).

When human capital is plentiful, the focus can be on which employee to dismiss, which to retain, and which to reward - and for those purposes, traditional models with the focuses on individual accountability fit well. But when talented employees are in shorter supply, as it is nowadays, developing and coaching people became a greater concern - and each company has to find new ways of meeting that need in order to improve their talent management and people development efforts (Cappelli - Tavis, 2016; Deloitte, 2015).

Emerging technologies - social media, mobile, analytics and cloud - are changing the way people work and interact with each other. Managers who used to engage with employees while communicating face to face are being replaced by remote teams that communicate via e-mail, chat, or Skype. Nowadays new collaboration tools combined with deep analytics enable companies to collect and shift through massive amounts of disparate information to uncover who is doing what and how well they are doing it (Bogar King et al., 2013).

In the knowledge era economy, the special knowledge generating resources required to foster innovation are no longer concentrated geographically and possessed by a single corporation, but rather distributed around the globe through collectives known as value networks. 


\section{Internal situation}

In knowledge-intensive businesses human assets are the most important resource and the management of these assets, thus HRM becomes crucial.

Organizations that need to become adept at change for managing the complexity of today's businesses pursue to create an open, innovative and collaborative culture with participative management styles. In matrixed or team based organizational structures and flexible working environment (Bogar King et al., 2013) it is up to each individual to take charge of his/her own growth and pursue a career that is right for him/her (People \& Strategy, 2016). These organizations encourage people to seek out their roles and managers to support employees as they follow their interests. When self-motivated employees and managers actively engage in performance development behaviors, it has significant positive impact on the outcomes that are important to them individually and to the company collectively as an evolving organization (People \& Strategy, 2016). Generation Y and $\mathrm{Z}$ employees represent an increasing constituency of digital natives (Meretei, 2017). Social, gaming and mobile technologies from the consumer digital world have risen their level of expectations for work tools that allow for real-time, farflung collaboration and contextual feedback. Leading companies which tend to attain the new generations of talent are adapting old-school processes and tools to more effectively compete with their competitors (Bogar King et al., 2013). Technology makes transparent goal setting and agile PM easier (Deloitte, 2015), while many companies are able to collect more performance data (e.g. customer feedback, peer reviews, social media comments, operational data) through systems that automate real-time analyses (Ewenstein, 2016).

\section{Organizational structure}

Nowadays the nature of work is shifting. Employees can work together from anywhere whether they are off-site, at home or in the field. They are mobile and no longer need to bind together by place. Due to the information technology developments, companies can make it easy for collaboration to happen anywhere and anytime to increase greater workplace flexibility which leads to improved performance and productivity. Teams are frequently formed, dissolved, and reformed time-to-time, based on the ever-changing business needs (Bogar King et al., 2013).

In many organizations the organizational structures became flatter, which promotes employee involvement through decentralized decision-making process, and as a result, employee empowerment and participation are increased. Collaborative network structures within and between firms, matrix, teamand project-organization structures are most suitable for organizations operating in a fast changing and dynamic environment (Bogar King et al., 2013; Rock - Jones, 2015).

Managers need to make it clear to the employees what kind of behaviors and per $\neg$ formance is expected by creating tight alignment between the work of the individual and the organization's objectives, that also promotes greater context, commitment, and job satisfaction. There is a shortened timeorientation in business cycles, projects are short-term and tend to change along the way. Jobs became more complex and require more skills, so it is difficult to set annual goals that is still meaningful a year later (Cappelli - Tavis, 2016).

Based on the "Theory Y" approach of McGregor it is discussed that subordinates should help set their performance goals and assess themselves by receiving feedbacks from the boss (McGregor, 1957). This process would build on the strengths and potential of the employees. However, the drawback of this approach is that doing the process right takes supervisors several days per employee each year (Rock - Jones, 2015). In case of flattened hierarchy structures the number of direct-reports which supervisors had to manage are higher. The employee-supervisor relationship and communication is informal, direct and participative. Hierarchy is established for convenience, superiors are always accessible and rely on individuals and teams for their expertise. Decision-making and information is shared between the different levels of leadership, which increase employee empowerment, participation, and efficiency (Cappelli - Tavis, 2016).

\section{Introduction to the "competitive" and to the "cooperative" approaches}

I identified nine features to describe and demonstrate the difference between the so called "traditional approach" and the "emerging trends" of PM systems: time-orientation, goal, focus, direction, objective settings and evaluation, measurement, development, manager's role, and rewarding performance. I name the so called traditional approach as competitive approach and the emerging trend as cooperative approach of PM systems since these represent more the main characteristics of both approaches.

\section{Competitive approach}

In this model, business objectives and strategies are cascaded down the organizations, since business goals are easy to articulate and held constant over the course of a year. The competitive models have a clear-cut way of tying rewards to individual contributions and have heavy emphasis on financial rewards and punishments and their end-of-year structure. They hold people accountable for past behavior at the expense of improving current performance and grooming talent for the future, both of which is critical for an organization's long-term survival in a fast-changing environment (Cappelli - Tavis, 2016).

When human capital is plentiful, the focus can be on which employee to dismiss, which to retain, and which to reward - and for those purposes, traditional appraisals with the emphases on individual accountability fit well. It is based on the assumption that some employees are fundamentally more talented than others, since there are fixed personality traits which make certain people better in the job. This is a weakness-based approach, in which the goal of the PM system is to identify and dismiss poor performers and retain and reward those good performers by applying external rewards. Managers prefer hiring rather than internal development to foster competition (Buckingham - Goodall, 2015).

The manager is in the role of the evaluator by following a formalized process and routine: filling out objective setting forms, tracking a process, conducting a formal annual review and assessment (Bogar King et al., 2013). The PM process is strongly determined by a numerical, year-end forced rating sys- 
tem and consensus meeting to compare people with one another (Buckingham - Goodall, 2015; Cappelli - Tavis, 2016).

\section{Cooperative approach}

In this approach PM closely follows the natural cycle of work. Conversations occur when projects end, milestones are reached, challenges pop up, and that allows people to solve problems in current performance while also developing skills for the future. This requires regular, practically continuous evaluation, informal check-ins, and real-time feedback (Buckingham - Goodall, 2015). These systems by moving away from forced ranking and from appraisal focus on individual accountability makes it easier to foster teamwork (Cappelli - Tavis, 2016).

In this outcome-focused approach employers would rather fuel current and future performance and groom talent for the future via instant feedbacks and time-to-time evaluations than conduct time-consuming annual performance reviews to hold people accountable for past behaviour (Cappelli - Tavis, 2016).

As Generation Y expand to dominate the workforce pioneer organizations are searching for social tools and applications to access in-the-moment feedback from peers, customers, and other stakeholders to promptly increase performance (Bogar King et al., 2013).

Managers take the lead in setting near-term goals and support their team-members as coaches (People \& Strategy, 2016; Barry et al., 2014). The assumption is that managers can change the way employees perform through effective coaching and intrinsic rewards such as personal growth and a sense of progress on the job by building on their strengths. The aim is to retain current employees by investing in them through development- and talent programs, rather than hiring human resources from outside the company (Cappelli - Tavis, 2016).

Employee goals may be pegged to specific projects. As projects unfold and tasks change it is difficult to coordinate individual priorities with the goals for the whole company, especially when the business objectives are short-term and must rapidly adapt to market shift.

Companies would rather apply qualitative judgments than numerical ratings. However, many companies (e.g. Deloitte and $\mathrm{PwC}$ ) are struggling to go entirely without ratings and they are trying a so called "third way": assigning multiply ratings several times a year. Nevertheless, annual final score serves as a starting point for compensation decisions, not the ending point (Buckingham - Goodall, 2015; Cappelli - Tavis, 2016). With or without ratings, many companies decided to follow shorter evaluation cycles, decentralize goal settings, and determine quantitative and qualitative measurement of contribution, impact, and value (People \& Strategy, 2016).

However, those companies changing their systems are still trying to figure out how their new practices will affect the payfor-performance model, which none of them have explicitly abandoned, they still differentiate rewards and set pay increases accordingly. Employees may receive bonuses after project ends or small weekly bonuses when they are doing good things. Even the evaluation is usually relying on managers' qualitative judgements rather than numerical ratings.

The cooperative approach emphasizes principles such as collaboration, self-organization, self-direction, and regular reflection on how to work more effectively, with the aim of responding in real time to customer feedback and changes in requirements. At the same time this approach requires a cultural shift by moving to an informal system where self-motivated employees and managers actively engage in performance development behaviors: direct managers take an active role in coaching and employees take charge of their own growth and drive career conversations throughout the year (Barry et al., 2014) (Table 2).

Table 2 Comparison of the "competitive" and the "cooperative" approach

\begin{tabular}{|c|c|c|}
\hline & Competitive & Cooperative \\
\hline $\begin{array}{l}\text { Time- } \\
\text { orientation }\end{array}$ & $\begin{array}{l}\text { Accountability for } \\
\text { past } \\
\text { performance }\end{array}$ & $\begin{array}{l}\text { Fuelling present } \\
\text { and future } \\
\text { performance }\end{array}$ \\
\hline Goal & $\begin{array}{l}\text { Identifying and di- } \\
\text { smissing poor per- } \\
\text { formers, retaining } \\
\& \text { rewarding good } \\
\text { performers (exter- } \\
\text { nal rewards) }\end{array}$ & $\begin{array}{l}\text { Coaching and } \\
\text { mentoring (internal } \\
\text { rewards) }\end{array}$ \\
\hline Focus & Process-focused & Outcome-focused \\
\hline Direction & Top-down & Bottom-up \\
\hline $\begin{array}{l}\text { Objective } \\
\text { settings \& } \\
\text { evaluation }\end{array}$ & $\begin{array}{l}\text { Annual cycle, } \\
\text { cascading } \\
\text { objectives once-- } \\
\text { a-year reviews }\end{array}$ & $\begin{array}{l}\text { Real business cycle, } \\
\text { regular evaluation, } \\
\text { frequent, informal } \\
\text { check-ins, } \\
\text { real-time feedback }\end{array}$ \\
\hline Measurement & $\begin{array}{l}\text { Numerical, year- } \\
\text { end ratings, forced } \\
\text { distribution and } \\
\text { consensus meeting }\end{array}$ & $\begin{array}{l}\text { Qualitative judg- } \\
\text { ments rather than } \\
\text { numerical ratings }\end{array}$ \\
\hline Development & $\begin{array}{l}\text { Weakness-based } \\
\text { Hiring rather than } \\
\text { internal } \\
\text { development } \\
\text { Fostering } \\
\text { cooperation }\end{array}$ & $\begin{array}{l}\text { Strength-based } \\
\text { Retaining, develop, } \\
\text { rather than hiring } \\
\text { Fostering } \\
\text { competition }\end{array}$ \\
\hline $\begin{array}{l}\text { Manager's } \\
\text { role }\end{array}$ & Evaluator & Coach \\
\hline $\begin{array}{l}\text { Rewarding } \\
\text { performance }\end{array}$ & $\begin{array}{l}\text { Clear-cut way of } \\
\text { tying rewards to } \\
\text { individual contri- } \\
\text { bution }\end{array}$ & $\begin{array}{l}\text { Annual final score } \\
\text { as a starting point } \\
\text { for compensation } \\
\text { decisions, small } \\
\text { bonuses after pro- } \\
\text { ject ends }\end{array}$ \\
\hline
\end{tabular}

Regarding the practical applications Ikramullah et al. (2016) offers a comprehensive framework for professionals to assess how the stakeholders value the performance appraisal system in each quadrant. What do they value more and put in the first place regarding to the two axis of the competing values framework of effectiveness of a performance appraisal system: internal vs. external and flexibility vs. control focus. Based on the contingency theory the design of an organization and its subsystems must have a proper fit with the environment and its subsystems should be 
also consistent. Management can achieve this proper fit by satisfying and balancing internal needs and adapting to environmental circumstances. However, it can happen that the management fails to make a proper diagnoses and implement a new system accordingly. If there is a mismatch between espoused theory and theory-in-use in the organization this can be potentially problematic if the company enforces its espoused theory by implementing a new PM system but the theory-in-use would indicate other models of performance appraisal system (Argyris - Schön, 1978).

At Intel in a two-year pilot, employees got feedback but no formal appraisal scores. Though supervisors could manage to differentiate performance and distribute performance-based pay, the top management returned to use ratings again in order to foster competition and clear outcomes (Cappelli - Tavis, 2016).

Based on contingence theory the elements of the internal environment, the so-called capabilities such as core processes and information technology, origin of the company, scope of activity, organizational size are given in the short-term and they can be changed only in long-term. Nevertheless, it could happen that one or more capabilities of the organization have to be changed in a short period of time which can have an effect on the competing values. In this case the implementation of a new PM system can foster the necessary change, however because of the big difference between the espoused theory and the theoryin-use of the organization, there is a jeopardy that after its implementation the system fails and the management returns to the old-system. The largest medical technology company, Medtronic, which gave up ratings several years ago, is reviving them after acquiring Ireland-based Covidien, which has different values and views of performance management (Cappelli - Tavis, 2016)

Others instead of reverting to the previous system try to seek middle ground. At PwC managers do not give a single rating annually, but employees get scores on five competencies along with other development feedback. The opposition to going completely numberless came from employees, especially those on a partner track, who want to know how they are improving (Eckersley, 2016). At New York Life, after the company ceased ratings, the merit-pay increases started to be interpreted as performance scores, which became known as "shadow ratings" and stared to have an effect on the talent management process. This lead the company to go back to its formal appraisal while keeping other changes such as quarterly conversations (Cappelli - Tavis, 2016). These show that the management not only have to make a proper diagnosis and implement a PM system accordingly, but it also has to review the fit with the environment and its subsystems time-to-time. By developing a tool the organization can explore those areas which need improvements.

All of the competing values may be present simultaneously in an effective performance appraisal system, but much more likely, there is a trade-off among these values. Some organizations may be effective when they are changing, adaptable and organic. In this case the cooperative type of PM system can support the organization better. If this adaptation and changing capability comes from the harmony in the internal characteristics of the organization the cooperative system may fit better to the human relations model. If the changing capability of the organization is rather derived from the interaction or the competition with other organizations in the market, the characteristic of the cooperative PM system can be compared more to the elements of open system model.

However some companies may be effective if they are stable, predictable and mechanistic. In line with this a competitive type of PM system can reinforce these capabilities of the organization better. If these characteristics are derived from capabilities comes from possessing harmony in the process internally, the competitive PM system may be more similar to the internal process model. If the organizations should rather focus on the external environment the competitive PM system may share more common traits with the rational goal model. The competitive system tends to focus more on the areas of the planning, goal-setting and the internal process-related factors, while the cooperative models shift the emphasis toward flexibility, adaptation, training, development and participation.

\section{How can PM system be improved?}

The effectiveness of PM system does not depend on whether it is similar either to the cooperative or the competitive model, but how the PM system is in line with the four criteria of the effectiveness and how the key stakeholders react to it and perceive its fairness in practice. According to Ikramullah et al. (2016) the utilization, qualitative and quantitative criterion is incomplete unless they are linked to the outcome criterion, that is the PM system can be considered effective when its key stakeholders top, middle and line management and employees consider it useful. The literature highlights that fairness perceptions are also one of the employees' reactions to PM system, and are related to the success and failure of system. In fact, when we are focusing on the qualitative criterion we foster the effectiveness of PM system regarding not just the outcome criterion but the utilization and quantitative criterion as well.

First, it is important that the development of a new system should start with a clear division of responsibilities between HR and the management. HR has responsibility for providing a framework with its expertise and enabling all the participants to build, use and review the system time to time. Participation and involvement of users in the design of the measurement tools and the components of the PM system is necessary (Guest - BosNehles, 2013; Longenecker - Fink, 2017; Gorman at al., 2017).

Secondly, HR should provide efficient support for top management to make a proper diagnosis and make decisions on the key elements (main purpose and features) of the new PM system according to the comprehensive framework for effectiveness of PM system in order to ensure that PM is designed in line with the organizational situation and business model. However after the system was set up continuous follow-up, monitoring and revision accordingly are also important (Longenecker - Fink, 2017).

Thirdly, one of its main success factors of effective PM system is its implementation. There is a difference between the presence of HR practice, that shows that the practice 
was once introduced and its quality, that reflects how it was implemented. Barney (2001) recognizes that 'the ability to implement strategies is, by itself, a resource that can be a source of competitive advantage" (Barney, 2001; p. 54 in Guest - Bos-Nehles, 2013). Becker and Huselid (2006) also argue that the effective HR strategy implementation as a key mediating variable between the HR architecture and firm performance (Guest - Bos-Nehles, 2013).

In fair implementation of PM practices the mediating role of line managers and HR support is important. In the followings I formulate some specific suggestions by which the effectiveness of PM presumable may be improved.

On the one hand, line managers may have a strong effect on employee perceptions, attitudes and behavior (Hartog et al., 2004; Guest - Bos-Nehles, 2013). The quality of implementation may vary because of time pressures and competing priorities or lack of knowledge, capability or even lack of belief in the likelihood that devoting time and energy to quality implementation will result in any pay-offs. However, in the right circumstances line managers will accept their HR responsibilities and implement HR practices effectively (Guest - Bos-Nehles, 2013). Line managers may need to be involved in the implementation and well trained to enable them to support their team as a coach, to share information, to set challenging yet attainable objectives, to track performance and give feedback frequently and to make a proper evaluation and create a climate in which people feel that they are treated fairly and high performance is stressed (Longenecker - Fink, 2017).

On the other hand HR role is to help in ensuring that what is implemented and experienced is aligned to what was intended by the top management (Farndale - Kelliher, 2013). It is especially important in headquarter-subsidiaries relations where other factors such as national cultures and legal context can play a part. In practice HR may help the management in creating an effective bottom-up and topdown communication flow to ensure that all the information was conveyed about the main purposes, the process and system, the consequences and the assessment tools to the participants (Gerákné, 2008b). HR also may provide trainings for employees for adopting an assertive behavior to express their opinions and emotions and to cultivate a supportive organizational culture where employees can raise their voices, tell their opinions about the evaluation, and that is taken into account (Gerákné, 2008b; Guest - Bos-Nehles, 2013). When employees perceive that the intended goals of HR practices are cost-driven, control-focused and unlikely to enhance employee well-being, they have lower levels of satisfaction and commitment. Lack of clarity and consistency is also more likely to cause varying attributions and responses among employees (Guest - Bos-Nehles, 2013).

$\mathrm{HR}$ is responsible for connecting the PM with other HR systems and processes and the results of the performance appraisal system serve not just valuable input in the decision making of compensation and benefits, succession planning, talent management, training and development (Gerákné, 2008b), but these links are also transparent for the employees.

\section{Further research directions}

PM are complicated activities involving a number of complex individual, procedural and organizational factors. In order to strengthen the credibility of PM practices it is necessary to find the missing link between individual-level performance and firm-level performance and to study the phenomenon of "reversed causality". It has always been assumed that increasing individual-level performance would lead to improvements in firm-level performance, but the researchers have failed to show clear evidence to prove the correlation (DeNisi - Murphy, 2017; Den Hartog et al., 2004). Regarding reversed causality some experts argue that the organizational success (e.g. profitability) could increase the willingness of top management to invest in HR practices rather than vica versa, and high organizational performance can also affect employees' commitment, trust, and motivation as much as the other way around (Den Hartog, 2004).

Like every HRM practices, PM systems can be seen as "signals" of the organization's intentions towards its employees and are interpreted as fair or unfair by each employees individually. This means that, employees do not automatically perceive these practices similarly or react to them in a similar manner (Den Hartog et al., 2004). There should be more research focus on the employees' reactions to PM practices, since employees' commitment and performance depends on their perception and evaluation of these practices, which is based on employee's previous experience, their beliefs, comparison to others (Guest, 1999 in Den Hartog et al., 2004) or their attributional styles (Harvey - Martinko, 2010). In order to study the antecedents and consequences of justice perception and different individual reactions to PM system and fairness perceptions and to bridge the gap between research and practice, more research is required, especially which focus on in real organizational settings by involving processes and outcomes with all stakeholders by applying more qualitative methods.

We need to improve our understandings about what determines effective HR implementation. Case studies in implementation by taking the middle management's view point could support PM practices not just to be present, but of a quality to be potentially effective (Guest - Bos-Nehles, 2013).

\section{References}

Aguinis, H. - Joo, H. - Gottfredson, R. K. (2011): Why we hate performance management - and why we should love it. Business Horizons, 54 (6), p. 503-507. doi:10.1016/j.bushor.2011.06.001

Argyris, C. - Schön, D. A. (1978): Organizational learning: A theory of action perspective. Reading. MA: Addison-Wesley Publishing Company

Bakacsi, Gy. - Bokor, A. - Császár, Cs. - Gelei, A. Kováts, K. - Takács, S. (1999): Stratégiai emberi erőforrás menedzsment. Budapest: Közgazdasági és Jogi Könyvkiadó

Barrier, M. (1998): Reviewing the annual review. Nation's Business, Volume 86., Issue 9 September 1998, p. 32-35.

Barry, L. - Garr, S. - Liakopoulos, A. (2014): Performance management is broken: Replace "rank and yank" 
with coaching and development. In: Global Human Capital Trends 2014: Engaging the 21st-century workforce, 2014, pp. 45-51. Retrieved 31052017 from: https://documents.dupress.deloitte.com/HCTrends2014

Berkics, M. (2008): A társadalmi viszonyok és a társadalomban zajló versengés igazságosságának észlelése, PHD.

Bies, R. J. - Moag, J. S. (1986): Interactional justice: Communication criteria of fairness. In: Lewicki, R. J. Sheppard, B. H. - Bazerman, M. H. (eds.): Research on Negotiations in Organizations. Vol. 1, Greenwich, CT: JAI Press, pp. 43-55.

Biron, M. - Farndale, E. - Paauwe, J. (2011): Performance management effectiveness: lessons from worldleading firms. The International Journal of Human Resource Management, Vol. 22, No. 6, pp. 1294-1311. doi.or $\mathrm{g} / 10.1080 / 09585192.2011 .559100$.

Bogar King, E. - Roddy, D. - Hodson, T. (2013): 2013 Human Capital Trends report - The Performance Management Puzzle Read. Deloitte. 2013. Retrieved 3105 2017 from: https:/www2.deloitte.com/be/en/pages/human-capital/articles/performance-management-puzzle. html

Bokor, A. (2011): A IV. HR-tükör kutatás legfontosabb eredményei - HR a válság idején. Vezetéstudomány/Budapest Management Review, 42 (4), pp. 2-18.

Boon, C. - Den Hartog, D. N. - Boselie, P. - Paauwe, J. (2011): The relationship between perceptions of HR practices and employee outcomes: examining the role of person-organisation and person-job fit. The International Journal of Human Resource Management, 22:1, pp. 138162., doi: 10.1080/09585192.2011.538978

Buckingham, M. - Goodall, A. (2015): Reinventing Performance Management: How one company is rethinking peer feedback and the annual review, and trying to design a system to fuel improvement. Harvard Business Review, 93(4), pp. 40-50.

Cappelli, P. - Tavis, A. (2016): The Performance Management Revolution: The focus is shifting from accountibility to learning. Harvard Business Review, October, pp. 57-67. Retrieved: 31052017 from https://hbr.org/2016/10/ the-performance-management-revolution.

Conlon, D. E. - Meyer, C. J. - Nowakowski, J. M. (2005): How does organizational justice affect performance, withdrawal and counterproductive behavior? In: Greenberg, J. - Colquitt, J. A. (2005): Handbook of Organizational Justice, Lawrence Erlbaum Associates, Inc. Publishers, pp. 301-327.

Colquitt, J. A. (2001): On the dimensionality of organizational justice: A construct validation of a measure. Journal of Applied Psychology. 86, pp. 386-400. http://dx.doi. org/10.1037/0021-9010.86.3.386.

Cook, K. - Hegtvedt, K. (1983): Distributive Justice, Equity, and Equality. Annual Review of Sociology, 9, pp. 217-241. Retrieved: 31052018 from http://www.jstor.org/ stable/2946064

Cropanzano, R. - Goldman, B. M. - Benson III, L. (2005): Organizational Justice. In: Barling, J. - Kelloway, E. K. - Frone, M. R. (2005): Handbook of Work Stress. Thousand Oaks: Sage Publications Inc., pp. 63-87.
Cropanzano, R. - Bowen, D. E. - Gilliland S. W. (2007): The management of organizational justice. Academy of Management Perspectives, November 1, 21(4), pp. 34-48. https://doi.org/10.5465/amp.2007.27895338

Deloitte (2011): Deloitte Centre for the Edge (2011). The 2011 shift index: Measuring the forces of long-term change. Deloitte Center for the Edge. Retrieved: 3105 2017 from: https://www2.deloitte.com/content/dam/ Deloitte/nl/Documents/center-for-the-edge/deloitte-nlcenter-for-the-edge-shift-index.pdf

Deloitte (2015): Global Human Capital Trends 2015: Leading in the new world of work. Retrieved from https:// www2.deloitte.com/au/en/pages/human-capital/articles/ global-human-capital-trends-2015-leading-new-world-work.html

Deloitte (2017): Global Powers of Retailing 2017: The art and science of customers. Retrieved: 31052018 from: https://www2.deloitte.com/content/dam/Deloitte/global/ Documents/consumer-industrial-products/gx-cip-2017global-powers-of-retailing.pdf

Den Hartog, D. N. - Boselie, P. - Paauwe, J. (2004): Performance Management: A Model and Research Agenda. Applied Psychology, 53, pp. 556-569. doi:10.1111/ j.1464-0597.2004.00188.x

DeNisi, A. S. - Pritchard, R. D. (2006): Performance Appraisal, Performance Management and Improving Individual Performance: A Motivational Framework. Management \& Organization Review, 2(2), pp. 253-277. https:// doi.org/10.1111/j.1740-8784.2006.00042.x

DeNisi, A. S. - Murphy, K. R. (2017): Performance appraisal and performance management: 100 years of progress? Journal of Applied Psychology, Mar,102(3), pp. 421-433. doi:10.1037/ap10000085.

Eckersley, D. (2016): Interview about „Redefining performance management. In: HCTV, Available at: https:// www.hcamag.com/tv/redefining-performance-management-at-pwc-215254.aspx

Erdogan, B. (2002): Antecedents and consequences of justice perceptions in performance appraisals. Human Resource Management Review, 12, pp. 555-578. http:// dx.doi.org/10.1016/S1053-4822(02)00070-0.

Ewenstein, B. - Hancock, B. - Komm, A. (2016): Ahead of the curve: The future of performance management. McKinsey Quarterly, (2), pp. 64-73.

Farndale, E. - Hope-Hailey, V. - Kelliher, C. (2011): High commitment performance management: the roles of justice and trust. Personnel Review, 40, 1, pp. 5-23. https://doi.org/10.1108/00483481111095492.

Farndale, E. - Kelliher, C. (2013): Implementing Performance Appraisal: Exploring the Employee Experience. Human Resource Management, 52, 6, pp. 879-897. https:// doi.org/10.1002/hrm.21575.

Gerákné Krasz, K. (2008a): A teljesítményértékelés igazságossága a szervezeti teljesítményértékelés észlelt igazságossága a szervezeti kultúra függvényében. PhDértekezés. Budapest: Eötvös Loránd Tudományegyetem

Gerákné Krasz, K. (2008b): Hogyan lehet igazságos a teljesítményértékelés. Munkaügyi Szemle, 52:(2), pp. 43-49. 
Goodman, D. - French, P. E. - Battaglio, Jr. R. P. (2015): Local Government Human Resource Management Past, Present, and Future: Revisiting Hays and Kearney's Anticipated Changes a Decade Later. The American Review of Public Administration, 45(2), pp. 135-152. https:// doi.org/10.1177/0275074013486179.

Gorman, C. A. - Meriac, J. P. - Roch, S. G. - Ray, J. L. Gamble, J. S. (2017): An exploratory study of current performance management practices: Human resource executives' perspectives. International Journal of Selection and Assessment, 25(2), pp. 193-202. http://dx.doi.org/10.1111/ijsa.12172

Greenberg, J. - Bies, J. R. (1992): Establishing the role of empirical studies of organizational justice in philosophical inquiries into business ethics. Journal of Business Ethics, Vol. 11, Issue 5-6., pp. 433-444.

Guest, D. E. - Bos-Nehles, A. C. (2013): HRM and performance: The role of effective implementation. In: J. Paauwe, J. - Guest, D. E. - Wright, P. W. (eds.): HRM and performance: Achievements and challenges. Chichester: Wiley, pp. $79-96$.

Harvey, P. - Martinko, M. J. (2010): Attribution Theory and Motivation. In: Chapter 7, Burlington: Jones and Bartlett Publishers, pp. 147-164.

Hays, S. W. - Kearney, R. C. (2001): Anticipated Changes in Human Resource Management: Views from the Field. Public Administration Review, 61., pp. 585-597. doi:10.1111/0033-3352.00129.

Ikramullah, M. - Van Prooijen, J. - Iqbal, M. - UlHassan, F. (2016): Effectiveness of performance appraisal. Personnel Review, 45, 2, pp. 334-352. http://dx.doi. org/10.1108/PR-07-2014-0164.

Iqbal, M. Z. - Akbar, S. - Budhwar, P. (2015): Effectiveness of performance appraisal: an integrated framework. International Journal of Management Reviews, Vol. 17 No. 4, pp. 510-533. https://doi.org/10.1111/ijmr.12050.

Kinley, N. (2016): The end of performance management: sorting the facts from the hype. Strategic HR Review, Vol. 15 Iss: 2, pp.90 - 94. https://doi.org/10.1108/SHR-09-2015-0081.

Lawrence, P. - Lorsch, J. (1967): Differentiation and integration in complex organizations. Administrative Science Quarterly, 12(1), pp. 1-30.

Longenecker, C. - Fink, L. (2017): Lessons for im-proving your formal performance appraisal process. Stra- tegic HR Review, Vol. 16 Issue: 1, pp.32-38. https://doi. org/10.1108/SHR-11-2016-0096.

McGregor, D. (1957): The Human Side of Enterprise. Management Review, 46 (11), pp. 22-28.

Meretei, B. (2017): Generációs különbségek a munkahelyen - szakirodalmi áttekintés. Vezetéstudomány/ Budapest Management Review, 48 (10), pp. 10-18. DOI https://doi.org/10.14267/VEZTUD.2017.10.02.

Murphy, K. R. - DeNisi, A. (2008): A model of the performance appraisal process. In: Varma, A. - Budhwar, P. - DeNisi, A. (eds.): Performance management systems around the globe. London, UK: Routledge, pp. 81-96.

People \& Strategy (2016): Riding the Performance Management Rollercoaster. People \& Strategy, 39(3), pp. 8-14. The Free Library, Conference notes, People \& Strategy. Vol. 39, issue 3. Retrieved 31052017 from: https:// www.thefreelibrary.com/Riding the performance management rollercoaster.-a0458159871

Rock, D. - Jones, B. (2015): Why More and More Companies Are Ditching Performance Ratings. Harvard Business Review Digital Articles, pp. 2-4. Retrieved from https:/hbr.org/2015/09/why-more-and-more-companies-are-ditching-performance-ratings.

Sass, J. (2011): Szervezeti érzelmek és szervezeti bizalom. Budapest: Budapesti Corvinus Egyetem

Szilas, R. F. (2014): A szervezeti igazságosság hatása a munkahelyi stressz kialakulásának folyamatára. Munkaügyi Szemle, Online 2014/1, pp. 56-65.

Takács, S. (2001): A vezetők és beosztottak céljai a teljesítményértékelés során - egy hazai felmérés eredményei. Vezetéstudomány, 11, pp. 31-41.

Zillman, C. (2017): IBM Is Blowing Up Its Annual Performance Review 2016. Retrieved 31052018 from: http:// fortune.com/2016/02/01/ibm-employee-performance-reviews/

Walsh, B. M. (2003): Perceived fairness of and satisfaction with employee performance appraisal. Dissertation. Louisiana State University.

WorldatWork and Sibson Consulting (2010): Study on the State of Performance Management. Retrieved: 3105 2017 from https:/www.worldatwork.org/docs/researchand-surveys/2010-study-on-the-state-of-performance-management.pdf. 